удК 338.242 .4

\title{
ОПТИМІЗАЦІЯ СИСТЕМИ УПРАВЛІННЯ СУЧАСНИМ БІЗНЕС-СЕРЕДОВИЩЕМ
}

\section{OPTIMIZATION OF THE MANAGEMENT SYSTEM OF THE MODERN BUSINESS ENVIRONMENT}

\author{
Біла Ірина Сергіївна \\ кандидат економічних наук, доцент, \\ Національний університет «Києво-Могилянська академія» \\ ORCID: https://orcid.org/0000-0002-2000-6198 \\ Насікан Ніна Іванівна \\ кандидат економічних наук, доцент, \\ Київський національний лінгвістичний університет \\ ORCID: https://orcid.org/0000-0001-6990-8584 \\ Bila Iryna \\ National University "Kyiv-Mohyla Academy" \\ Nasikan Nina \\ Kyiv National Linguistic University
}

\begin{abstract}
Розвинене та дієве бізнес-середовище $є$ передумовою використання потенціалу бізнесу, підвищення ефективності та стабільності ринкової економіки. Управління бізнес-середовищем вважається одним із напрямів поліпшення його якості, яка в свою чергу є узагальнюючим результатом його фуннкціонування. Суб'єктний підхід до аналізу процесу управління бізнес-середовищем дозволяє стверджувати, що означена система функціонує на рівні таких її суб'єктів як держави, бізнес-асоціацій та підприємств та визначається адекватністю їх дій. На думку авторів, процес порушення чи руйнування цілісності взаємодії зазначених суб'єктів є деструкцією, головним фрактором якої є особистісний фрактор. Саме зорієнтованість суб'єктів - держави, бізнес-асоціацій та підприємств - на реалізацію власних інтересів, а не на потреби партнера цілісної системи, підриває стабільність системи управління бізнес-середовищем та актуалізує питання оптимізації - тобто знаходження такого стану та умов бізнес-середовища, які забезпечують найвищу ефективність взаємодії його суб'єктів.

Ключові слова: бізнес-середовище, система управління бізнес-середовищем, держава, бізнес-асоціації, підприємство, бізнес, бізнесовий сектор, деструкція системи управління бізнес-середовищем, оптимізація системи управління бізнес-середовищем.
\end{abstract}

Развитая и действенная бизнес-среда является предпосылкой использования потенциала бизнеса, повышение эфрфективности и стабильности рыночной экономики. Управление бизнес-средой считается одним из направлений улучшения ее качества, в свою очередь является обобщающим результатом ее функционирования. Субъектный подход к анализу процесса управления бизнес-средой позволяет утверждать, что данная система фрункционирует на уровне таких ее субъектов как государства, бизнес-ассоциаций и предприятий и определяется адекватностью их действий. По мнению авторов, процесс нарушения или разрушения целостности взаимодействия указанных субъектов является деструкцией, главный фрактор которой - личностный. Именно ориентация субъектов - государства, бизнес-ассоциаций и предприятий - на реализацию собственных интересов, а не на потребности партнера целостной системы, подрывает стабильность системы управления бизнес-средой и актуализирует вопрос оптимизации - нахождения такого состояния и условий бизнессреды, которые обеспечивают высочайшую эффрективность взаимодействия его субъектов.

Ключевые слова: бизнес-среда, система управления бизнес-средой, государство, бизнес-ассоциации, предприятие, бизнес, деловой сектор, деструкция системы управления бизнес-средой, оптимизация системы управления бизнес-средой.

A developed and efficient business environment is a prerequisite for using the potential of business, increasing the efficiency and stability of a market economy. Management of the business environment is considered one of the ways to improve its quality, which in turn is a generalized result of its operation. This system operates at the level of 
its subjects such as the state, business associations and enterprises and is determined by the adequacy of their actions. According to the authors, the process of violating or destroying the integrity of the interaction of these subjects is destruction, the main factor of which is the personal factor. It is the focus of the subjects - the state, business-associations and enterprises - on the realization of their own interests, rather than on the needs of a partner of a holistic system, undermines the stability of the business environment management system and raises the issue of optimization. The purpose of the article is to optimize the business environment management system, to provide the system with the most favorable characteristics, determine the optimal conditions for its development and determine the impact of these conditions on the quality of the business environment. The achievement of this goal was achieved through the systematization of literature sources on the selected problem, own research and considerations. According to the authors, the criterion for optimizing the functioning and development of the management system of the business environment, the objective function of this system is its quality. The highest level of development of the business environment management system can be achieved in the case of using each of its elements of the subsystem in its activities, the principle of responsibility. The authors came to the conclusion, that the implementation of this principle in the management system of the business environment has the following features: each of the subjects of interaction should be guided in their actions by openness; the state must be a model, a subject of social responsibility, but enterprises and business organizations must also be guided by high values; social responsibility can be transformed into social benefit - the overall positive effect generated by coherence, the general direction of their actions to change and change; the stability of the business environment management system is ensured by the ability of subjects to self-development and self-improvement with the dominance not of the personal factor, but of the interests of the whole society.

Keywords: business environment, business environment management system, state, business-associations, enterprise, business, business sector, destruction of business environment management system, optimization of business environment management system.

Постановка проблеми. Розвинене та дієве бізнес-середовище $\epsilon$ передумовою використання потенціалу бізнесу та підвищення ефективності і стабільності ринкової економіки. Управління бізнес-середовищем $€$ складним процесом цілеспрямованого впливу на бізнесову діяльність 3 метою ії спрямування на вирішення проблем соціально-економічного розвитку. Сучасне бізнес-середовище характеризується багатоманітністю впливів та мінливістю, що зумовлює наявність фракторів, які порушують або навіть призводять до руйнації системи управління ним. Деструктивні фрактори призводить до небажаних змін структури, змісту, срункцій, властивостей, параметрів та результатів орункціонування системи управляння бізнес-середовищем. Основним деструктивним фрактором, на наше переконання, $€$ особистісний фрактор на рівні будь-якої підсистеми-елемента системи управління бізнессередовищем. У зв'язку із вищезазначеним, особливої актуальності набуває дослідження оптимізації системи управління бізнес-середовищем, тобто надання зазначеній системі найвигідніших характеристик, визначення оптимальних умов її розвитку та з'ясування впливу цих умов на якість сорормованого бізнес-середовища. Останнє здатне не тільки зменшити невизначеність бізнес-середовища, але й стати запорукою у нівелюванні наслідків негативних впливів і посиленні позитивних діянь.

Аналіз останніх досліджень і публікацій. Дослідження теоретичних та прикладних аспектів розвитку бізнес-середовища $є$ досить актуальною проблемою економічної науки.
Серед вчених, які досліджували названу проблематику слід відзначити Боброва В., Буряка Г., Мельника М., Набока Ю., Пархоменко Н., Страшного С., Сурай А., Труніну І., Швеця Г. та ін. Вченими проаналізовані підходи до дослідження бізнес-середовища і його складових, аспекти його державного регулювання, стан, діагностику, особливості і проблеми розвитку бізнес-середовища в Україні, в тому числі враховуючи регіональні та глобальні аспекти проблематики тощо.

Виділення невирішених раніше частин загальної проблеми. Однак, незважаючи на численні публікації та їх значну наукову цінність, дослідження системи управління сучасним бізнес-середовищем в аспекті їі оптимізації потребує подальших досліджень.

Формулювання цілей статті (постановка завдання). Мета статті - здійснити оптимізацію системи управління бізнес-середовищем, тобто надати зазначеній системі найвигідніших характеристик, визначити оптимальні умови її розвитку та з'ясувати вплив цих умов на якість сорормованого бізнес-середовища.

Виклад основного матеріалу дослідження. Дослідження нами системи управління бізнес-середовищем має чітку структуру та логіку. Останнє включає розуміння сутності бізнес-середовища; дослідження процесу управління бізнес-середовищем через аналіз його суб'єктів - держави, бізнес-асоціацій та підприємств; визначення деструктивних оракторів цілісної системи управління бізнес-середовищем та як кінцевий результат - здійснення оптимізації названої системи. 3 метою представлення ціліс- 
них результатів наших досліджень, вважаємо за необхідне нагадати ключові моменти. Так, в економічній літературі під бізнес-середовищем прийнято розуміти сукупність всіх зовнішніх фракторів діяльності підприємства, які суттєво впливають на його функціонування.

3 метою підвищення якості бізнес-середовища здійснюється процес управління ним. Під управлінням бізнес-середовищем розуміємо процес цілеспрямованого прямого чи опосередкованого впливу на зовнішні фрактори фрункціонування бізнесу з метою його спрямування на вирішення проблем соціально-економічного розвитку. Варто підкреслити, це процес управляння бізнес-середовищем, є цілісною системою, яка складається із відповідних підсистемелементів, та має високий рівень ефективності саме за рахунок їх взаємодії. В разі використання суб'єктного підходу до аналізу системи управління бізнес-середовищем, можна дійти до таких висновків: ця система, включає підсистеми-елементи управління на рівні таких суб'єктів бізнес-середовища, як держави, бізнес-асоціацій та підприємств та визначається адекватністю їх дій [2].

Кожен із названих суб'єктів здійснює вплив на зовнішні фрактори функціонування бізнесу, та має набір інструментів, цілей та завдань розвитку. Держава, на наше переконання, має найбільші можливості впливу на його складові, а визначення міри їі участі $€$ складною соціально-економічною проблемою теорії i практики. Технологія взаємодії держави і бізнесу визначається наявністю різних інституційних суб'єктів у частині побудови механізму управління такою взаємодією. Важлива роль у даній взаємодії відводиться різним асоціаціям та об'єднанням бізнесу. Останні є дієвою фрормою самоорганізації бізнесового співтовариства, виступають своєрідними посередниками у налагоджені діалогу між бізнесом і владою, виконують роль експертів у сферах практичної реалізації проектів, планів і ініціатив. Подібна взаємодія між державою, бізнес-асоціаціями та бізнесовим сектором нагадує тріалектику таку фрорму взаємодії, за якої крім двох протилежностей - держава і бізнесовий сектор 3 їх різними інтересами - присутній третій сполучний елемент - бізнес-асоціації - через які $€$ можливості вирішити протиріччя і організувати спільний взаємовигідний діалог [2].

Економічна дійсність мінлива, характеризується впливом багатьох фракторів, які порушують чи навіть руйнують цілісність взаємодії його суб'єктів - це фрактори деструкції. На наше переконання, основним фрактором деструкції досліджуваної системи є особистісний фактор на рівні будь-якої підсистеми-елемента системи управління бізнес-середовищем. Так, на рівні держави останнє виражається у непрофесіоналізмі представників органів державної влади, їх прагнення до реалізації власних інтересів на противагу інтересам бізнесових груп, корупційної діяльності, бажання узурпувати владу та прагнення до авторитаризму тощо. На рівні бізнес-асоціацій особистісний фрактор втілюється у прагнення лобіювати інтереси не всього бізнесового співтовариства, а окремих його представників та діянь на їхню користь. Стосовно рівня підприємств, то це виражається у недотриманні принципів соціальної відповідальності бізнесу, використанні недобросовісної конкуренції та нечесних методів боротьби, створенні заборонених законодавством союзів з метою максимізації власної вигоди, співпрацюванні із кримінальними угрупуваннями тощо. Значна деструкція системи управління бізнес-середовищем сприяє виникненню аномії, яка характеризується послабленням порядку взаємодії суб'єктів системи, розпадом цінностей їх взаємозв'язків без наявної альтернативи. Таке явище здатне дезорганізувати соціально-економічні структури, порушити суспільну рівновагу та звести зусилля суб'єктів управління нанівець [1].

У зв'язку із викладеним вище, гостро постає питання оптимізації системи управління бізнес-середовищем. Оптимізація будьякої системи пов'язана із вибором критерію оптимізації. Означене питання $€$ одним із найскладніших та охоплює велику «творчу, креативну» складову. Загальними вимогами до критерію оптимізації $€$ наступні: він має виражатися за допомогою кількісних показників; бути в тій чи іншій мірі єдиним «мірилом» певного процесу чи явища; відображати найбільш істотні сторони досліджуваної системи та бути логічним і легким для розрахунків.

Будь-який критерій оптимізації включає три види параметрів - вхідні, вихідні та регульовані. На нашу думку, вхідними параметрами системи управління бізнес середовища $\epsilon$ наявні ресурси, як матеріальні, так і нематеріальні, встановлене нормативно-правове поле, як своєрідне «місце гри» для національних суб'єктів, усталені традиції та культура взаємодії, наприклад у вигляді сорормованого конкурентного середовища. Варто відмітити, що держава, яка, як вже зазначалося раніше, має найбільші можливості впливу в означеній системі управління, керуючись в тій чи іншій мірі суспільними цілями здатна змінювати вхідні 
параметри. Вихідними параметрами є параметри, що виражають певний результат - обсяг доходу (прибутку), рівень мінімізації витрат ресурсів, місце на ринку тощо. Найціннішими параметрами з боку керуючої системи $є$ регульовані параметри. Ці параметри мають двоїсту природу - 3 одного боку, вони $є$ складовими критерія оптимізації, a, з іншого боку, саме за рахунок ним відбуваються зміни у вхідних параметрах, що в свою чергу визначають результативність цілісної системи.

Найбільш логічним, на наше переконання, $€$ припущення, що критерієм оптимізації фрункціонування та розвитку системи управління бізнес-середовищем $€$ її якість. Якість сорормованого бізнес-середовища визначається:

- результативністю, яка проявляється у наявності таких зовнішніх умов розвитку бізнесу, які здатні забезпечити високий сукупний результат його фрункціонування, представлений кількісними та якісними показниками, та існуючою відповідність результатів діяльності бізнесового сектору до цілей його фрункціонування, а також до наявного потенціалу для подальшого розвитку;

- ефрективністю, що виражається у здатності бізнесового сектору приносити ефект суспільству та кожному його суб'єкту, який визначається як відношення результату (наприклад, показників діяльності бізнесу, місце бізнесового сектору у різноманітних міжнародних рейтингах тощо) до витрат, що забезпечили цей результат (наприклад, втрати ресурсів, податкових надходжень в разі існування податкових преференцій, бюджетних коштів в разі існування державної грошової підтримки тощо);

- адаптивністю - здатність бізнесового сектору до пристосування до змін в умовах їх бізнес-середовища, швидкої орієнтації в діяльності в межах національної економіки [1].

Враховуючи той фракт, що основним деструктивним чинником системи управління бізнессередовищем є особистісний фрактор, логічно припустити, що найвищого рівня розвитку система управління бізнес-середовищем може досягти в разі використання кожною із її підсистем-елементів в своїй діяльності принципу відповідальності. В сучасній науці соціальна відповідальність розуміється як діалектичний взаємозв'язок між індивідом і суспільством, поєднує певні права і обов'язки, а також певні засоби у разі порушення суспільних норм. Соціальна відповідальність виражає систему суспільних відносин, сукупність добровільних і встановлених засобів щодо їх забезпечення, створення нормальних умов взаємодії всіх суб'єктів, гарантування їх стабільності.

Враховуючи суб'єктний підхід до системи управління бізнес-середовищем, необхідно зазначити що взаємодія держави, бізнес-асоціацій та підприємств на основі принципів соціальної відповідальності здатна забезпечити високу якість означеної системи. Реалізація зазначеного принципу в даній системі має такі особливості:

- кожен із суб'єктів взаємодії мають керуватися у своїх діях відкритістю - до нових ідей та методів організації і управління, до поширення інсрормації, до нових «сигналів ринку», до налагодження взаємодії один із одним, до змін;

- держава, на нашу думку, хоч і має бути взірцем, суб'єктом поширення соціальної відповідальності, але й підприємства та бізнесорганізації мають діяти за принципом «хто, як не я», тобто соціальна відповідальність має бути керована високими ціннісними орієнтирами, як компонентами свідомості;

- усвідомлення суб'єктами управління бізнес-середовищем, що соціальна відповідальність здатна перетворюватись у соціальну вигоду - еклектичний, сумарний позитивний есрект породжений злагодженістю, спільною направленістю їх дій у бік перетворень та змін;

- стабільність системи управління бізнессередовищем забезпечується стійкістю самих суб'єктів - держави, бізнес-асоціацій та підприємств - їх здатністю до саморозвитку та самовдосконалення із домінуванням не особистісного фрактору, а інтересів всього суспільства.

Висновки. Вплив соціальної відповідальності на якість системи управління бізнессередовищем реалізується через вигоди, які вони отримують:

- формування ефрективних механізмів соціального діалогу між всіма суб'єктами - державою, бізнес-асоціаціями та підприємствами;

- досягнення суспільних цілей і реалізація стратегій соціально-економічного розвитку шляхом консолідації зусиль держави, потенціалу бізнесового сектору та бізнес-асоціацій;

- покращення ділової репутації як окремих компанії, так і країни в цілому, транслювання їх відповідального ставлення один до одного, до споживачів, конкурентів, довкілля, ресурсів;

- покращення механізмів використання ресурсів на рівні країни та підвищення конкурентоспроможності окремих підприємств, національного бізнесового сектору;

- отримання бізнесом гарантій щодо захисту своїх інтересів та наявність захисту від корупції та ситуацій, за яких інтереси держави підміняються інтересами окремих ії представників тощо. 


\section{СПИСОК ВИКОРИСТАНИХ ДЖЕРЕЛ:}

1. Біла І.С., Насікан Н.І. Деструкція системи управління сучасним бізнес-середовищем. Східна Європа: економіка, бізнес та управління. 2020. № 2(25). URL: http://www.easterneurope-ebm.in.ua/journal/25_2020/15.pdf

2. Біла І.С., Насікан Н.І. Ієрархія суб'єктів управління бізнес-середовищем: держава - бізнес-асоціації - підприємства. Східна європа: економіка, бізнес та управління. 2019. № 3(20). URL: http:// www.easterneurope-ebm.in.ua/20-2019-ukr

\section{REFERENCES:}

1. Bila I.S., Nasikan N.I. (2020) Destruktsiia systemy upravlinnia suchasnym biznes-seredovyshchem [Destruction of the management system of the modern business environment]. Eastern Europe: Economy, Business and Management (electronic journal), vol. 2(25). Available at: http://www.easterneurope-ebm.in.ua/ journal/25_2020/15.pdf

2. Bila I.S., Nasikan N.I. (2019) ljerarkhija sub'jektiv upravlinnja biznes-seredovyshhem: derzhava - biznesasociaciji - pidpryjemstva [The hierarchy of business management entities: state - business associations enterprises]. Eastern Europe: Economy, Business and Management (electronic journal), vol. 3(20). Available at: www.easterneurope-ebm.in.ua/20-2019-ukr 